\title{
Correction to: Don Ihde: Husserl's Missing Technologies
}

Fordham University Press, New York (Perspectives in Continental

Philosophy), 2016, vxiii + 157 pp. US $\$ 85.00$ (hardbound), US $\$ 24.00$ (paper), US \$23.99 (eBook), ISBN 978-0-8232-6961-7

\section{Lee Hardy ${ }^{1}$}

Published online: 31 August 2018

(c) Springer Nature B.V. 2018

\section{Correction to: Husserl Studies \\ https://doi.org/10.1007/s10743-018-9232-9}

In the original publication of an article the name "Idhe" occurs incorrectly including in the very beginning, in the title of the review. Now the correct name has been published in this correction.

Correct name is 'Ihde'.

The original article can be found online at https://doi.org/10.1007/s10743-018-9232-9.

Lee Hardy

lhardy@calvin.edu

1 Department of Philosophy, Calvin College, 1845 Knollcrest Circle SE, Grand Rapids, MI 49546, USA 